Check for updates

Cite this: RSC Adv., 2017, 7, 42407

Received 8th August 2017

Accepted 26th August 2017

DOI: $10.1039 / c 7 r a 08765 a$

rsc.li/rsc-advances

\section{Structural transformation of selenate ettringite: a hint for exfoliation chemistry $\dagger$}

\begin{abstract}
Binglin Guo, (D) Keiko Sasaki* and Tsuyoshi Hirajima
Exfoliation of layered materials has attracted tremendous interest since nanomaterials have become practically applied in many disciplines. In this study, the structural transformation of packed columnar selenate ettringite into nanoscale particles has been investigated. The structural transformation of ettringite has been evidenced based on the results of X-ray diffraction (XRD), Raman spectroscopy, transmission electron microscopy (TEM), and extended $\mathrm{X}$-ray adsorption fine structure (EXAFS). The structural transformation is caused by the electrostatic repulsion between guest sulfate ions and selenate. However, the atomic arrangement of columnar parts of selenate ettringite is still maintained. In addition, a similar phenomenon is more noticeably observed when it is soaked in ethanol. This suggests that this columnar material has the potential to be exfoliated into a single nanoscale column by reactions with polar solvents. Finally, a stable colloidal solution formed when selenate ettringite was soaked in butanol. This is because the surface of the columnar parts in ettringite is surrounded by structural water molecules that can interact with $\mathrm{OH}$ groups of strongly polar solvent molecules to form hydrogen bonds that can directly exfoliate selenate ettringite and convert to nanoparticles. It is clear that ettringite could be directly exfoliated to nanoparticles in polar organic solvents, which has potential utility for wide applications.
\end{abstract}

\section{Introduction}

Delamination/exfoliation of low-dimensional solids on the nanoscale level has attracted significant interest, which has benefited both fundamental research and practical applications in the fields of electronic, photonic, construction, and engineering materials. ${ }^{1}$ Recently, the majority of the work in the area of delamination has been focused on layered structured materials, such as montmorillonite (Mt), layered double hydroxides (LDHs), inorganic-organic framework materials, and titanates. ${ }^{1-4}$ These layered materials can be delaminated by reactions with surfactants and organic solvents as a result of the swelling of the layers, leading to an increase in the number of effective reaction sites. Among these layered materials, the chemical and physical properties of LDHs exfoliation have been extensively investigated. The delaminated LDHs were explored for their use as catalysts, drug delivery systems, and cement additives after integration and reassembly. ${ }^{5-7}$ However, delamination/exfoliation of other compounds has not been significantly investigated and reported. Thus, the development of new materials that could be exfoliated into the nanoscale may

Department of Earth Resources Engineering, Kyushu University, Fukuoka 819-0395, Japan. E-mail: keikos@mine.kyushu-u.ac.jp; Fax: +81-92-802-3338; Tel: +81-92-8023338

$\dagger$ Electronic supplementary information (ESI) available: Figures showing a schematic illustration of the ettringite crystal structure; XRD patterns of the solid residues before and after selenate ettringite soaking in ethanol. See DOI: 10.1039/c7ra08765a also attract tremendous interest from fundamental research and practical applications.

Ettringite $\left(\mathrm{Ca}_{6} \mathrm{Al}_{2}\left(\mathrm{SO}_{4}\right)_{3}(\mathrm{OH})_{12} \cdot 26 \mathrm{H}_{2} \mathrm{O}\right)$ is the prototype of hydroxyl-sulfate phase. It is well-known that this mineral usually occurs at a low temperature in hydrothermal mineral deposits, alkaline evaporates and xenolith environments. ${ }^{8}$ In addition, this compound also forms via the hydration of calcium aluminates in the presence of sulfate during the early hydration process of Portland cement. ${ }^{9}$ Particularly, ettringite is well-known as an anion-exchanger, and the generic formula for ettringite could be expressed as $\left[\mathrm{M}_{x}{ }^{2+}\left(\mathrm{M}^{3+}\right)_{x / 3}(\mathrm{OH})_{12}\right]\left[\mathrm{A}^{n-}\right]_{x / n}$. $26 \mathrm{H}_{2} \mathrm{O}$, where $\mathrm{M}^{2+}$ is a divalent cation, including $\mathrm{Ca}^{2+}, \mathrm{Sr}^{2+}$, $\mathrm{Pb}^{2+}, \mathrm{Co}^{2+}, \mathrm{Zn}^{2+}$, etc. ${ }^{10-12} \mathrm{M}^{3+}$ is a trivalent cation, including $\mathrm{Al}^{3+}$, $\mathrm{Ga}^{3+}, \mathrm{Fe}^{3+}, \mathrm{Mn}^{3+}, \mathrm{Cr}^{3+}$, etc. ${ }^{\mathbf{1 3 , 1 4}}$ and $\mathrm{A}^{n-}$ is an $n$-valent anion, including $\mathrm{Cl}^{-}, \mathrm{SO}_{4}{ }^{2-}, \mathrm{SeO}_{4}{ }^{2-}, \mathrm{AsO}_{4}{ }^{3-}$, etc. ${ }^{10,15-17}$ Based on the previously reported structure model of ettringite, ${ }^{18}$ the unit cell mainly consists of column parts $\left.\left\{\mathrm{Ca}_{6}\left[\mathrm{Al}(\mathrm{OH})_{6}\right]_{2} \cdot 24 \mathrm{H}_{2} \mathrm{O}\right]\right\}^{6+}$ that are constituted by $\mathrm{Al}(\mathrm{OH})_{6}{ }^{3-}$ octahedra and $\mathrm{Ca}-\mathrm{O}_{8}$ polyhedra. In the columnar parts, each $\mathrm{Ca}$ is eight coordinated by four $\mathrm{H}_{2} \mathrm{O}$ and four $\mathrm{OH}^{-}$ions. This means that the $\mathrm{Al}(\mathrm{OH})_{6}{ }^{3-}$ octahedra and $\mathrm{Ca}-\mathrm{O}_{8}$ polyhedra share $\mathrm{OH}^{-}$ions. $\mathrm{SO}_{4}{ }^{2-}$ ions and $\mathrm{H}_{2} \mathrm{O}$ molecules occupy the intercolumn space, which holds the column portions together for structural stability via electrostatic forces (Fig. S1 in the ESI $\dagger$ ). ${ }^{\mathbf{1 0} 18}$ Additionally, a precise arrangement of the hydrogen bonding network exists in ettringite. ${ }^{\mathbf{1 9}}$

In a similar manner to LDHs, high concentrations of anionic species and water molecules are present within the intercolumnar spaces of ettringite and interact with the high charge 
density of the columnar regions. This results in strong intercolumnar electrostatic interactions and distinctive hydrophilic properties in the intercolumnar spaces, which can lead to the strong hydrogen bonding network and electrostatic forces for the compact stacking of the column structure, preventing the exfoliation of ettringite. ${ }^{18,19}$ Meanwhile, the size and electronegativity of the substituting anions are determinants for substitution in the intercolumnar spaces. ${ }^{15}$ These provide some hints that the van der Waals interactions that exist among the intercolumnar spaces of the stacked columns could be weakening via the interaction with ions or molecules. The exfoliation of ettringite can generate novel research fields dealing with the preparation of new and advanced functional materials. Since ettringite has an excellent ion-exchange capacity and is composed of positively charged columns, exfoliation of this material can produce positively charged and nanoscaled columns that can be applied as nanocomposites for producing polymers or designed nanomaterials similar to the applications of delaminated LDHs to various areas such as catalysis, drug delivery systems, advanced materials, etc.

In the present study, selenate ettringite $\left(\mathrm{Ca}_{6} \mathrm{Al}_{2}\left(\mathrm{SeO}_{4}\right)_{3}\right.$ $\left.(\mathrm{OH})_{12} \cdot 26 \mathrm{H}_{2} \mathrm{O}\right)$ was synthesized by coprecipitation, and its destructuralization was observed when this material was soaked in a sulfate solution. In addition, the columnar structure of the destructuralized ettringite was maintained as confirmed via its characterization by a variety of techniques. Moreover, the selenate ettringite could be destructuralized and exfoliated in some strongly polar solvents. The nanoparticles of exfoliated ettringite were characterized via atomic force microscopy observation (AFM). The exfoliation of the material with the columnar structure to nanoparticles was demonstrated, and its exfoliation mechanism was also detailed. The special exfoliation property of ettringite may open up new opportunities for producing the nanoparticles dispersed inorganic solvents, which have potential in many applications.

\section{Materials and methods}

Deionized water and reagent-grade chemicals (Wako Pure Chemical Industry, Japan) were used to prepare all solutions. Acid and ultrapure water-washed beakers, flasks, and centrifuge tubes were used in all experiments. $\mathrm{Na}_{2} \mathrm{SeO}_{4}, \mathrm{AlCl}_{3} \cdot 6 \mathrm{H}_{2} \mathrm{O}$, $\mathrm{Ca}(\mathrm{OH})_{2}, \mathrm{NaOH}$, ethanol, and butanol were used as supplied.

\subsection{Material preparation}

Selenate-substituted ettringite was synthesized via coprecipitation: $0.445 \mathrm{~g}$ of powdery $\mathrm{Ca}(\mathrm{OH})_{2}$ was introduced into a $100 \mathrm{~mL}$ solution of $20 \mathrm{mM} \mathrm{AlCl} 3 \cdot 6 \mathrm{H}_{2} \mathrm{O}$ and $30 \mathrm{mM} \mathrm{Na} \mathrm{SeO}_{4}$ to obtain a theoretical molar ratio $(3: 1)$ of $\mathrm{Ca}: \mathrm{Al}$ in ettringite. The mixtures were subsequently covered with parafilm to avoid $\mathrm{CO}_{2}$ contamination and then thoroughly mixed using a magnetic stirrer for $24 \mathrm{~h}$ at room temperature. Afterward, suspensions were filtered through a $0.2 \mu \mathrm{m}$ membrane filter (Advantec, Tokyo, Japan) to provide solutions for determining the residual $\mathrm{Ca}, \mathrm{Al}$, and Se concentrations via inductively coupled plasma optical emission spectrometry (ICP-OES, Perkin Elmer, Optima
8300, US). The precipitates were dried in silica gel in desiccators under mild vacuum conditions for one week to remove excess water. Then, the dried solid residues were provided for characterization as described below.

\subsection{Material destructuralization and exfoliation}

Because sulfate ions show a higher affinity to ettringite than selenate, ${ }^{15,24} 20 \mathrm{mg}$ of selenate ettringite was added to $50 \mathrm{~mL}$ of 0.001-10 $\mathrm{mM} \mathrm{Na}_{2} \mathrm{SO}_{4}$ for destructuralization. Since ettringite is an alkaline material and stable at $\mathrm{pH}$ values higher than $10.7,{ }^{17}$ the initial $\mathrm{pH}$ was adjusted to $12.00 \pm 0.01 \mathrm{using} 0.1 \mathrm{mM} \mathrm{NaOH}$. The suspensions were constantly shaken at $100 \mathrm{rpm}$ for $2 \mathrm{~h}$. The residual $\mathrm{Ca}, \mathrm{Al}, \mathrm{Se}$, and $\mathrm{S}$ concentrations in the aqueous solution were determined, and the solid residues were collected for characterization. Separately, exfoliation was conducted using ethanol and butanol, and $20 \mathrm{mg}$ of selenate ettringite was added to $50 \mathrm{~mL}$ of the ethanol or butanol and were constantly shaken at $100 \mathrm{rpm}$ for $2 \mathrm{~h}$ for destructuralization.

\subsection{Characterization}

2.3.1. Powder $X$-ray diffraction. After the reaction, the solid residues were characterized using powder XRD on an Ultima IV (RIGAKU, Akishima, Japan). The XRD patterns were collected at $40 \mathrm{kV}$ and $40 \mathrm{~mA}$ using a diffraction beam graphitemonochromator with $\mathrm{Cu} \mathrm{K} \alpha$ radiation in the range from $5^{\circ}$ to $70^{\circ} 2 \theta$ with a step size of $0.02^{\circ}$ and a count time of $2 \mathrm{~s}$ for each step. XRD patterns were qualitatively analyzed using Rigaku PDXL software and reference patterns from the International Center for Diffraction Data database (ICDD, 2011).

2.3.2. Raman spectroscopy. Raman spectra were obtained using a JEOL JRS system 2000 Raman spectrometer (JEOL Ltd., Tokyo, Japan) (1800 lines per $\mathrm{mm}$ grating). An excitation wavelength of $514.5 \mathrm{~nm}$ was used for the argon ion laser. The laser beam was focused by a microscope equipped with $50 \times$ or $100 \times$ objectives, leading to a spot diameter of 2 or $1 \mu \mathrm{m}$, respectively.

2.3.3. Scanning electron microscopy/transmission electron microscopy. The representative samples were dispersed on double-sided carbon tape and supplied for scanning electron microscopy (SEM) using an accelerating voltage of $20 \mathrm{kV}$ on a VE-9800 spectrometer (Keyence, Osaka, Japan). The transmission electron microscopy (TEM) was observed with an FEI TECNAI-0 TEM (JEOL, Akishima, Japan) at an accelerating voltage of $120 \mathrm{kV}$. The samples for TEM observation were prepared by placing selected samples on copper grids coated with thin carbon films at room temperature.

2.3.4. EXAFS analysis. X-ray absorption fine structure (XAFS) spectra of Ca K-edge were collected in the fluorescence mode at room temperature on a BL 06 at the SAGA-LS (Saga, Japan) with the storage ring operating at energy of $1.4 \mathrm{GeV}$. The energy range of this light source (bending magnet) is 2.1$23 \mathrm{keV}$. A silicon (111) double-crystal monochromator was used to obtain the incident X-ray beam. The typical photon flux is $10^{10}$ photons per s. The intensities of the fluorescence X-rays were monitored with silicon drift detector. Ca K-edge spectrum was calibrated by $\mathrm{Ca}(\mathrm{OH})_{2}$ (Wako, special grade, Osaka, 
Japan) to $4038 \mathrm{eV}$. Pure sulfate ettringite (synthesized) ${ }^{23}$ were used as standard substances. All powder samples were diluted with BN (Wako, special grade, Osaka, Japan) to adjust to $2 \mathrm{wt} \%$ of Se and then pressed into a tablet with a diameter of $1 \mathrm{~cm}$.

Data processing was performed using IFEFFIT software package ver. 0.9.25 (ATHENA and ARTEMIS) via the following procedures. $^{20,21}$ The spectra were averaged after energy calibration. The $\chi(k)$ function was Fourier transformed through $k^{3}$ weighing and filtered using "HANNING" before Fourier transmission. The shell fit was operated in $R$-space on the first and second shells within the data range of $R+\Delta R=1-4 \AA$ using the single scattering model. The theoretical back-scattering path was calculated by ARTEMIS and FEFF using ettringite as the standard. The coordination number $(\mathrm{CN})$ of $\mathrm{Ca}$ for all modeled treatments was set at a theoretical value. Because the DebyeWaller factor $(\sigma)$ is correlated highly with CNs, $\sigma$ values for some shells were each fixed at their average values. Errors for the fit parameters were estimated from the fits of the model compounds. Errors are within $0.01 \AA$ for the $R$-value of the first shell and within $0.05 \AA$ for the additional shells. The coordination number errors are $\pm 20 \%$ for the first shells and $\pm 50 \%$ for the additional shells.

2.3.5. AFM observation. The topographical image of the exfoliated ettringite was observed using a SPS-1100 atomic force microscope (AFM, Seiko Instruments Inc., Chiba, Japan). Samples were prepared by adsorbing the nanoparticles from a suspension onto a newly exfoliated mica layer. The resulting single layer films were dried in an $\mathrm{N}_{2}$ gas flow. Measurements were conducted in tapping mode with silicon tip cantilevers.

\section{Results and discussion}

\subsection{Destructuralization of selenate ettringite}

The powder X-ray diffraction patterns (XRD) for the coprecipitated product without sulfate was confirmed to be the pure

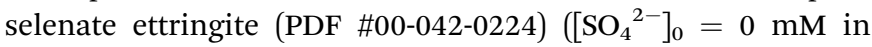
Fig. 1). Elemental analysis of selenate ettringite after digestion showed that the molar ratio of $\mathrm{Ca}: \mathrm{Al}: \mathrm{SeO}_{4}$ was $6: 1.9: 2.8$, respectively, which is in good agreement with a previous report. $^{22}$ In terms of destructuralization, the equilibrium concentrations of $\mathrm{Ca}, \mathrm{Al}$, and $\mathrm{Se}$ and their molar ratio in the solid residues after soaking as a function of the initial $\mathrm{SO}_{4}{ }^{2-}$ concentrations are summarized in Table 1. After soaking the selenate ettringite in $0-10 \mathrm{mM}$ sulfate, the remaining sulfate concentrations did not significantly change, and the molar ratio of $\mathrm{Ca}: \mathrm{Al}: \mathrm{SeO}_{4}$ in the solid was close to the theoretical one of $6: 2: 3$ in pure selenate ettringite (Table 1). This suggests that the selenate ettringite is mostly stable in a sulfate solution. In addition, slight dissolution of selenate ettringite was observed because this material can play a role as a buffer to maintain the solution $\mathrm{pH}$ at approximately $11.68 .^{17,23}$

Consistent with the water chemistry results, the changes in the XRD patterns of the solid residues as a function of the initial $\mathrm{SO}_{4}{ }^{2-}$ concentrations are provided (Fig. 1). When the concentrations of sulfate were lower than $0.1 \mathrm{mM}$, the solid residues exhibited sharp diffraction peaks corresponding to the pure selenate ettringite (Fig. 1). This indicates that the selenate ettringite structure is

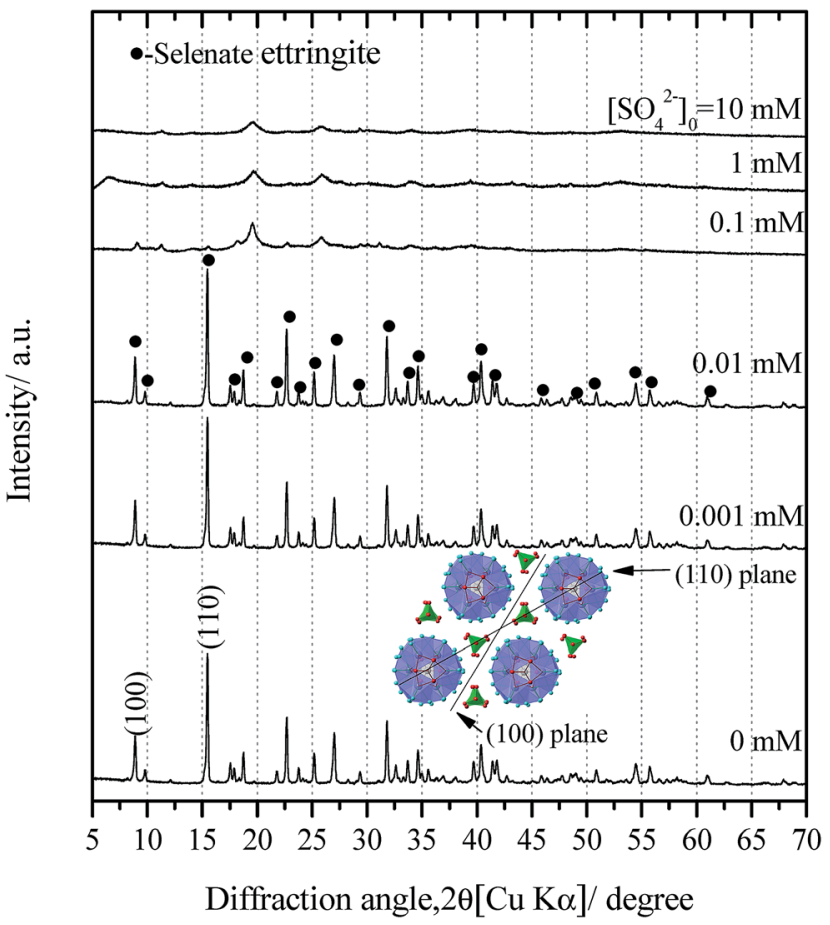

Fig. 1 XRD patterns of the solid residues after soaking pure selenate ettringite in 0-10 mM sulfate. Inset: perpendicular to $c$-axis shows the columns and channels of selenate ettringite with the (100) and (110) plane.

relatively stable and could be maintained in low concentrations of sulfate. However, the distinguished diffraction peaks, (100) and (110), of selenate ettringite gradually weakened and finally disappeared when the initial sulfate concentration exceeded $0.1 \mathrm{mM}$ (Fig. 1). Perhaps the crystal structural of selenate ettringite could have changed or decomposed after soaking in high concentrations of sulfate. Nevertheless, some broad peaks still were present even though the distinguished diffraction peaks of selenate ettringite had already disappeared, implying that the atomic arrangement of ettringite was partially preserved.

In term of morphology changing of soaked samples, the SEM images of the solid residues of selenate ettringite with or without soaking in $10 \mathrm{mM}$ sulfate were observed, as shown in Fig. 2(a) and (b). Pure selenate ettringite exhibited the typical needle-like morphology that was approximately $2 \mu \mathrm{m}$ in width and $15 \mu \mathrm{m}$ in length (Fig. 2(a)), this is consistent with the typical morphology of ettringite., ${ }^{9,15}$ The particle size and the aspect ratio of the $10 \mathrm{mM}$ sulfate soaked selenate ettringite decreased compared with the pure selenate ettringite (Fig. 2(b)). In addition, the TEM images of pure and destructuralized selenate ettringite were compared in Fig. 2(c) and (d). The pure selenate ettringite crystals exhibited a well compacted and homogeneous morphology (Fig. 2(c)). In contrast, the destructuralized selenate ettringite showed some disordered and heterogeneous regions for the solid residues, indicating changes in the crystal structure and destructuralization of the soaked selenate ettringite (Fig. 2(d)). Based on the SEM and TEM images, perhaps the sulfate exchanged with selenate in ettringite and destructuralized the crystal structure of selenate ettringite. 
Table 1 Concentrations of $\mathrm{Ca}, \mathrm{Al}$, and $\mathrm{Se}$ after the soaking experiment as a function of the initial $\mathrm{SO}_{4}{ }^{2-}$ concentrations with the $\mathrm{Ca}: \mathrm{Al}$ : Se molar ratio in the solid residues

\begin{tabular}{llllll}
\hline $\begin{array}{l}\mathrm{SO}_{4}{ }^{2-} \text { initial } \\
\text { concentration } \\
\mathrm{mmol} \mathrm{L}^{-1}\end{array}$ & $\begin{array}{l}\mathrm{SO}_{4}{ }^{2-} \text { equilibrium } \\
\text { concentration } \\
\mathrm{mmol} \mathrm{L}^{-1}\end{array}$ & $\begin{array}{l}\text { Ca equilibrium } \\
\text { concentration } \\
\mathrm{mmol} \mathrm{L}^{-1}\end{array}$ & $\begin{array}{l}\text { Al equilibrium } \\
\text { concentration } \\
\mathrm{mmol} \mathrm{L}^{-1}\end{array}$ & $\begin{array}{l}\text { Se equilibrium } \\
\text { concentration } \\
\mathrm{mmol} \mathrm{L}^{-1}\end{array}$ & $\begin{array}{l}\mathrm{Ca}: \mathrm{Al}:(\mathrm{Se}+\mathrm{S}) \\
\text { molar ratio in solids }\end{array}$ \\
\hline 0.000 & $0.000 \pm 0.000$ & $1.323 \pm 0.002$ & $0.569 \pm 0.004$ & $0.635 \pm 0.005$ & $5.9: 2: 2.8$ \\
0.001 & $0.001 \pm 0.000$ & $1.312 \pm 0.004$ & $0.573 \pm 0.007$ & $0.635 \pm 0.002$ & $5.9: 2: 2.8$ \\
0.009 & $0.009 \pm 0.000$ & $1.321 \pm 0.001$ & $0.571 \pm 0.006$ & $0.692 \pm 0.003$ & $5.9: 2: 2.8$ \\
0.093 & $0.091 \pm 0.001$ & $1.274 \pm 0.003$ & $0.527 \pm 0.008$ & $0.663 \pm 0.006$ & $5.9: 2: 2.8$ \\
0.963 & $0.957 \pm 0.001$ & $1.211 \pm 0.004$ & $0.513 \pm 0.004$ & $0.624 \pm 0.010$ & $5.9: 2: 2.8$ \\
9.879 & $9.723 \pm 0.002$ & $1.183 \pm 0.014$ & $0.503 \pm 0.026$ & $0.584 \pm 0.004$ & $5.9: 2: 2.8$
\end{tabular}

Considering that ettringite consists of positively charged columnar parts with intercolumn oxoanions, the destructuralization of selenate ettringite may also affect its surface charge. The changes in the zeta potential of the solid residues as a function of the concentrations of sulfate are shown in Fig. 3. The $\mathrm{pH}$ of the zero point of charge $\left(\mathrm{pH}_{\mathrm{zpc}}\right)$ of selenate ettringite is approximately $13 .{ }^{24}$ When the concentration of sulfate was lower than $0.1 \mathrm{mM}$, the surface of selenate ettringite was positively charged. This is consistent with the above results that showed that the crystal structures of selenate ettringite were maintained with a positively charged surface at $\mathrm{pH} \leq 12$. When the sulfate concentrations were increased from $0.1 \mathrm{mM}$ to $10 \mathrm{mM}$, the surface charge of the selenate ettringite gradually decreased from approximately $2 \mathrm{mV}$ to $-11 \mathrm{mV}$. Of note, when the distinguished diffraction peaks of selenate ettringite disappeared (Fig. 1), the surface charge became negative (Fig. 3). Moreover, it is well known that the zeta potential is the electric potential in the diffuse double layer (DDL) at the slipping plane, and it is associated with swelling of solid materials in aqueous systems. ${ }^{25}$ Changes in the crystal structure and surface charge might be attributed to the swelling and partial stripping of selenate ettringite. The well-crystallized selenate ettringite only exposes the positively charged columnar edge, which resulted in the positive charge. In contrast, when the crystal structure of selenate ettringite was destructuralized, the surface charge became negative (Fig. 3). This may be caused by the enlarged and exposed intercolumn space of ettringite after destructuralization. Thus, selenate and sulfate ions that were coordinated with the surface of the destructuralized and positively charged ettringite columns would affect the slipping plane of the particles, resulting in the reversal of the surface charge.

The partial atomic arrangement in the destructuralized selenate ettringite column was still maintained, although the distinguishing peaks were no longer observed in the XRD
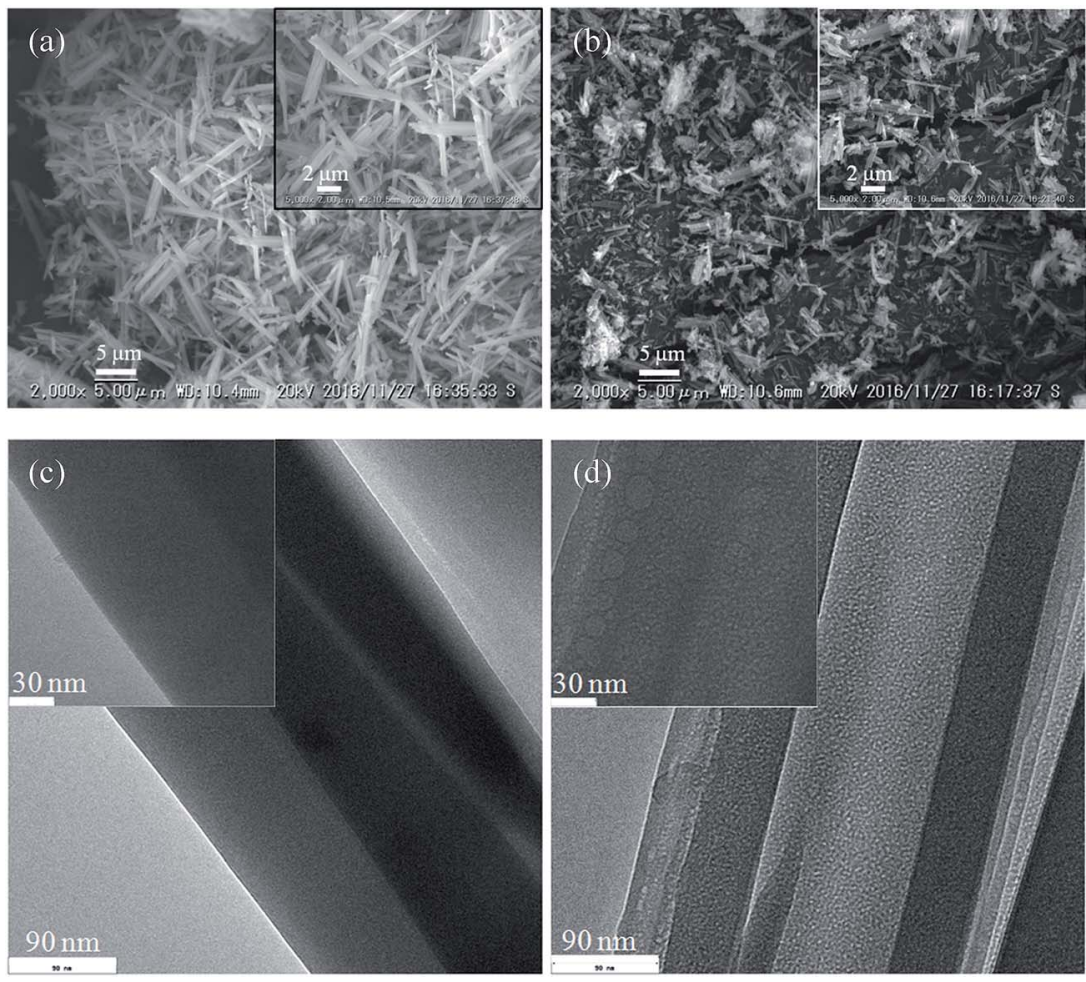

Fig. 2 SEM images of the solid residues (a) before soaking and (b) after soaking. TEM images of the solid residues (c) before and (d) after soaking. 


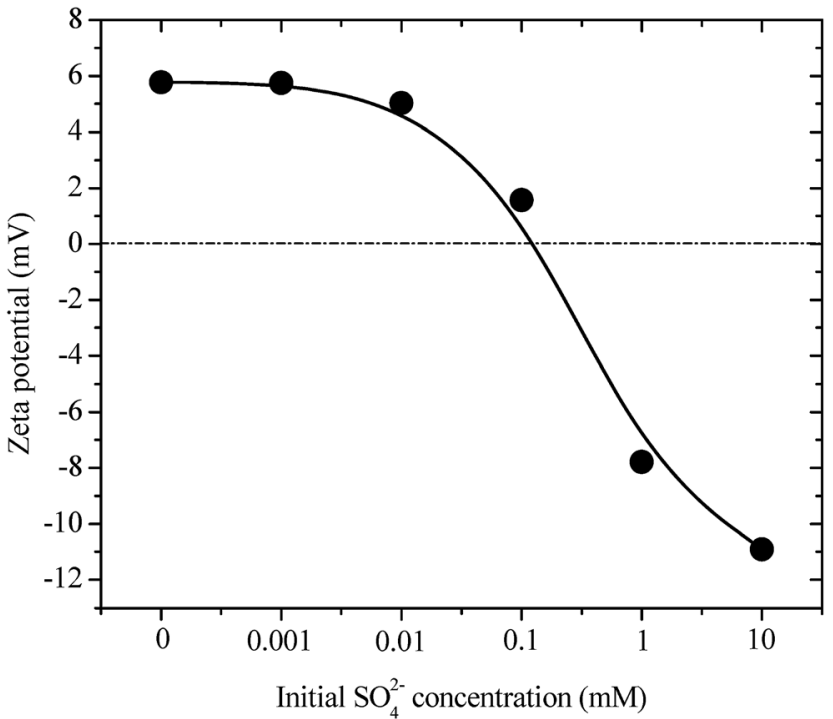

Fig. 3 Zeta potentials of pure selenate ettringite after soaking at various initial $\mathrm{SO}_{4}{ }^{2-}$ concentrations.

patterns (Fig. 1). Fig. 4 shows the Raman spectrum of the soaked selenate ettringite in $10 \mathrm{mM}$ sulfate, which possessed bands at $\sim 345 \mathrm{~cm}^{-1}, \sim 415 \mathrm{~cm}^{-1}, \sim 842 \mathrm{~cm}^{-1}$, and $\sim 884 \mathrm{~cm}^{-1}$ and are assigned to the vibration modes of $v_{2}\left(\mathrm{SeO}_{4}{ }^{2-}\right)$, $v_{4}\left(\mathrm{SeO}_{4}{ }^{2-}\right), v_{1}\left(\mathrm{SeO}_{4}{ }^{2-}\right)$, and $v_{3}\left(\mathrm{SeO}_{4}{ }^{2-}\right)$, respectively. ${ }^{27}$ This suggests that $\mathrm{SeO}_{4}{ }^{2-}$ groups were still present in the destructuralized selenate ettringite, although the peak intensities decreased compared with the original selenate ettringite. This might be due to the disordered and heterogeneous atomic arrangement of the destructuralized selenate ettringite structure, which is consistent with the TEM results (Fig. 2(d)). In addition, a weak and broadband at $\sim 980 \mathrm{~cm}^{-1}$ ascribed to the vibration mode of $v_{1}\left(\mathrm{SO}_{4}{ }^{2-}\right)$ in sulfate ettringite ${ }^{26}$ was barely observed in the soaked selenate ettringite. This indicates that

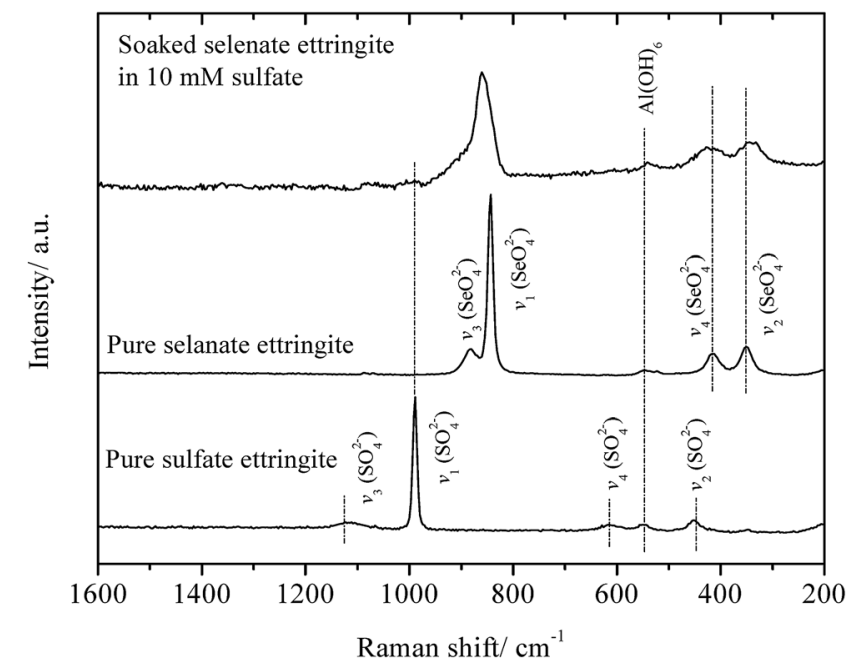

Fig. 4 Raman spectra of soaked ettringite and the related compounds. a trace amount of sulfate exchanged with selenate in ettringite. Specifically, the destructuralized selenate ettringite and standard compound exhibit a band at 530-540 $\mathrm{cm}^{-1}$ assigned to the $\mathrm{Al}-\mathrm{OH}$ vibration in ettringite, ${ }^{\mathbf{2 6 , 2 8}}$ implying that the $\mathrm{Al}(\mathrm{OH})_{6}{ }^{3-}$ octahedral structure was maintained in the solid residues even when the XRD pattern of selenate ettringite disappeared (Fig. 1).

EXAFS analysis was further conducted to elucidate the atomic configuration of the destructuralized selenate ettringite. The Ca K-edge EXAFS spectra of the destructuralized selenate ettringite and the standard compounds are shown in Fig. 5. For all of the samples, the Fourier transform is dominant by the first shell of backscattering from oxygen in Fig. 5(a). For the pure sulfate and selenate ettringite, every $\mathrm{Ca}$ atom is coordinated by $8 \mathrm{O}$ atoms. Four of the $\mathrm{O}$ atoms are provided by $\mathrm{OH}$, whereas the others are from $\mathrm{H}_{2} \mathrm{O}$ molecules at approximately $2.4 \AA$. In addition, the $2 \mathrm{Al}$ atoms were approximately fitted at $3.46 \AA$. The atomic distances of $\mathrm{Ca}-\mathrm{O}$ and $\mathrm{Ca}-\mathrm{Al}$ were firmly fit to the reported data. ${ }^{18}$ Furthermore, the destructuralized selenate ettringite exhibited a similar coordination number and atomic distance as $\mathrm{Ca}$ in prior references (Fig. 5 and Table 2). Considering the ettringite columnar parts are constituted by $\mathrm{Al}(\mathrm{OH})_{6}{ }^{3-}$ octahedra and $\mathrm{Ca}-\mathrm{O}_{8}$ polyhedra by sharing $\mathrm{OH}^{-}$ions (Fig. $\mathrm{S} 1(\mathrm{~b})$ in the $\mathrm{ESI} \dagger$ ), both the Raman and EXAFS results confirmed that the column structure of selenate ettringite was maintained after destructuralization of its crystal structure. We demonstrated that the columnar parts of selenate ettringite were stable even though this material was destructuralized in a sulfate solution. In addition, these results also confirmed that selenate ettringite has the potential to be exfoliated as nanoparticles.

Based on the structural properties of ettringite, the following destructuralization mechanism of selenate ettringite in sulfate solution was proposed. In the crystal structure of selenate ettringite, the positively charged columnar parts are bound by electrostatic forces through the interaction with intercolumn oxoanion species. ${ }^{\mathbf{1 0 , 1 8 , 2 9}}$ The sulfate ions have been confirmed to show a higher affinity to ettringite than selenate. ${ }^{\mathbf{1 5 , 2 4}}$ When the sulfate is intercalated into the intercolumn spaces of selenate ettringite, the guest sulfate ions disorder the charge balance and structure of ettringite. This is because the Pauling's electrostatic valence rule is exactly obeyed in ettringite. ${ }^{\mathbf{1 0 , 1 9}}$ The guest sulfate ions' intercalation will cause electrostatic repulsion with selenate and disorder the charge balance between columns in an aqueous system (Fig. 6). Therefore, as the surface charge changes, the diffraction peaks of selenate ettringite gradually weaken and finally disappear. However, the selenate ions are already settled on the surface of the columnar parts via hydrogen bonds, and guest anions are difficult to substitute with selenate ions. After the destructuralization of selenate ettringite, the guest sulfate ions are loosely bound on the surface of the columnar parts of selenate ettringite via electrostatic forces. Thus, the sulfate and selenate concentrations did not change significantly even though the distinguished diffraction peaks of selenate ettringite disappeared after destructuralization 

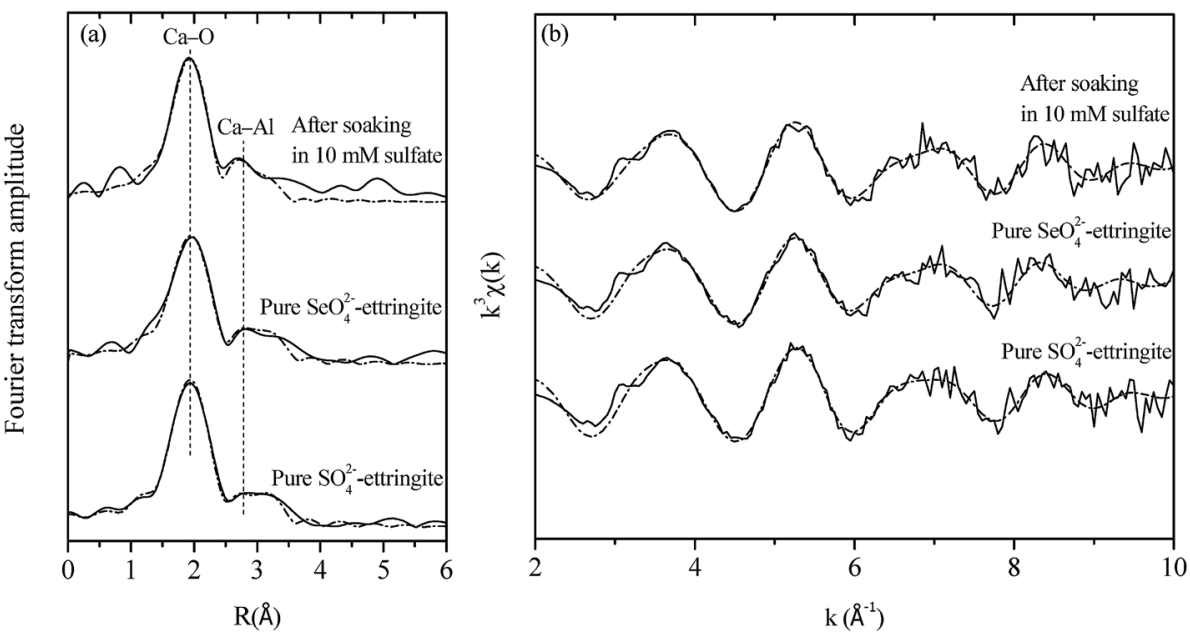

Fig. 5 (a) $k^{3}$-weighted Ca K-edge EXAFS data of solid residues before soaking and after soaking and reference compounds. (b) The corresponding Fourier transforms (not corrected for phase shift) showing both raw (solid lines) and fitted data (dash lines).

Table 2 Ca K-edge EXAFS fitting results of pure sulfate ettringite, selenate ettringite and the soaked compounds in $10 \mathrm{mM} \mathrm{Na}_{2} \mathrm{SO}_{4}$ Coordination number $(\mathrm{CN})$, interatomic distance $(R)$, and DebyeWaller factor $\left(\sigma^{2}\right)^{b}$

\begin{tabular}{llllll}
\hline Samples & Shells & CN & $R$ & $\sigma^{2}$ & $R_{\mathrm{f}}$ \\
\hline Pure sulfate ettringite & $\mathrm{Ca}-\mathrm{O}$ & $8^{a}$ & 2.43 & 0.012 & 0.021 \\
& $\mathrm{Ca}-\mathrm{Al}$ & $2^{a}$ & 3.46 & 0.006 & \\
Pure selenate ettringite & $\mathrm{Ca}-\mathrm{O}$ & 7.27 & 2.44 & 0.011 & 0.011 \\
& $\mathrm{Ca}-\mathrm{Al}$ & 1.82 & 3.48 & 0.005 & \\
After soaking & $\mathrm{Ca}-\mathrm{O}$ & 7.73 & 2.41 & 0.012 & 0.025 \\
& $\mathrm{Ca}-\mathrm{Al}$ & 1.93 & 3.43 & 0.007 &
\end{tabular}

${ }^{a}$ Value was fixed during the fitting procedure. ${ }^{b} R_{\mathrm{f}}$ residual factor indicates the quality of fitting results and is expressed by following formula: $R_{\mathrm{f}}=\frac{\sum_{i=1}^{n}\left(k^{3} \chi_{\exp }-k^{3} \chi_{\text {theo }}\right)^{2}}{\sum_{i=1}^{n}\left(k^{3} \chi_{\exp }\right)^{2}} \times 100$.

(Table 1). This is in agreement with other studies showing that oxoanions are difficult to substitute in ettringite structures after this mineral formation..$^{15,17}$

\subsection{Exfoliation of selenate ettringite}

As described in Section 3.1, selenate ettringite shows a potential for destructuralization after interaction with high electronegativity anions, which could affect and break up the crystal structure of this material. Nonetheless, it is difficult to exfoliate selenate ettringite via the direct reaction with high electronegativity anions because high concentrations of anionic species and water molecules exist in the intercolumnar spaces of ettringite and interact with the high charge density of the columnar regions. Thus, the hydrogen bonding network and electrostatic forces would again result in the stacking of the columnar parts.

Ettringite consists of columnar parts and larger intercolumn spaces (11-12 $\mathrm{A})$ than LDHs. ${ }^{10}$ Water molecules are linked to Ca and surround the surface of the ettringite columnar parts (Fig. S1(b) in the ESI $\dagger$ ). This results in a larger percentage of the surfaces of ettringite columnar parts being surrounded by water molecules, which have the possibility to react with some surfactants or organic solvents. Some organic solvents that contain $\mathrm{OH}$ groups have been confirmed to form hydrogen bonds with the structural water molecules in minerals. ${ }^{30,31}$ In addition, because the columnar constituted structure is more

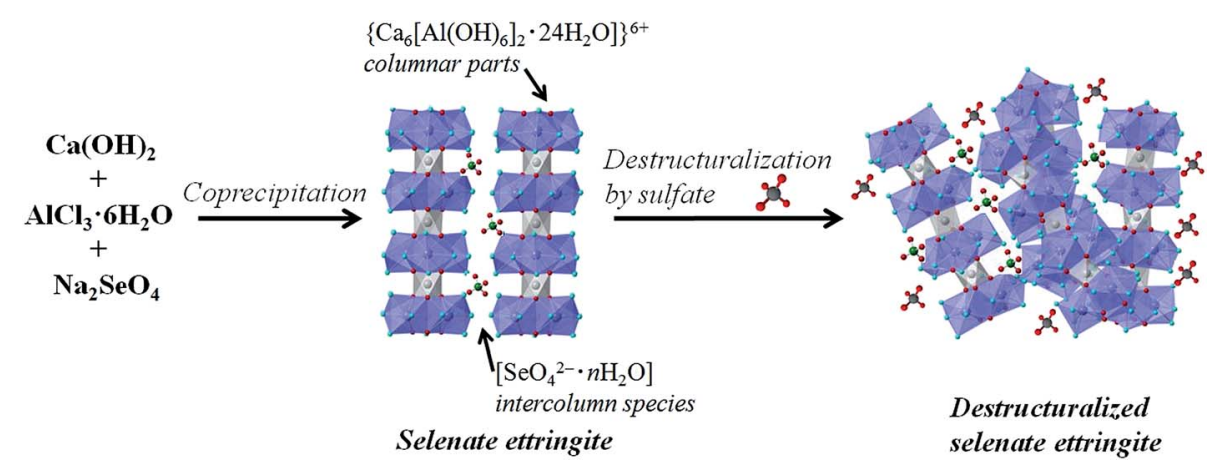

Fig. 6 Schematic illustration of the selenate ettringite synthesis and destructuralization in sulfate solution. 

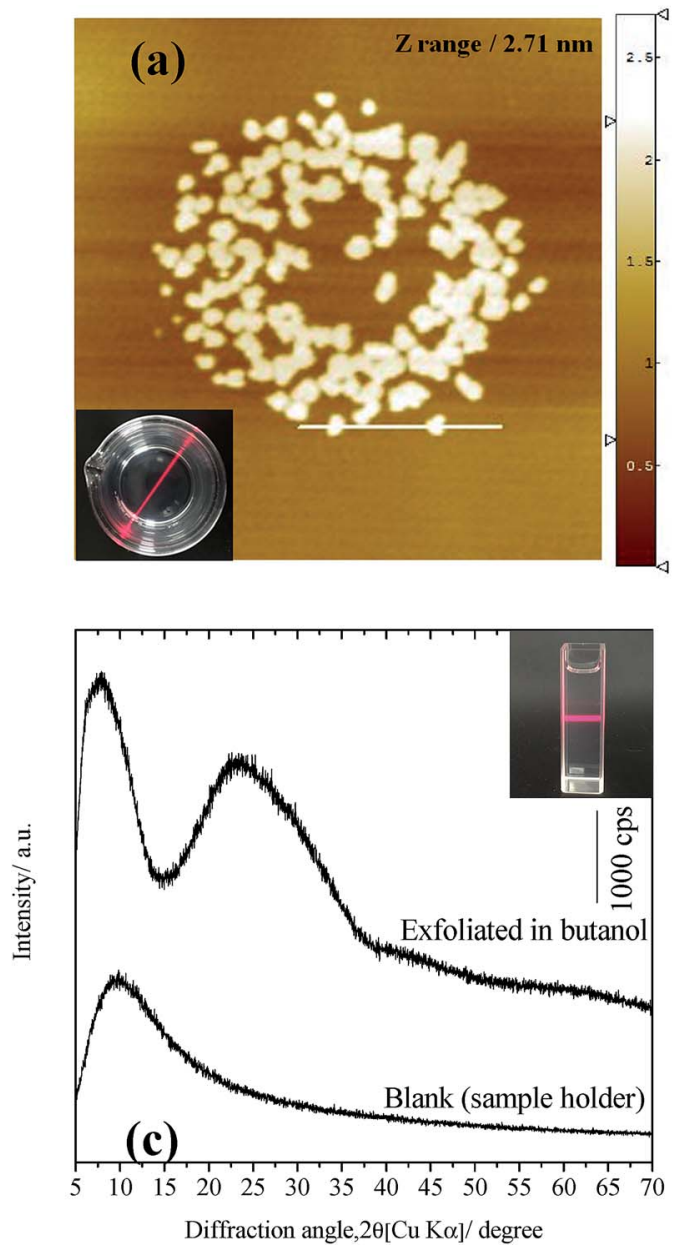
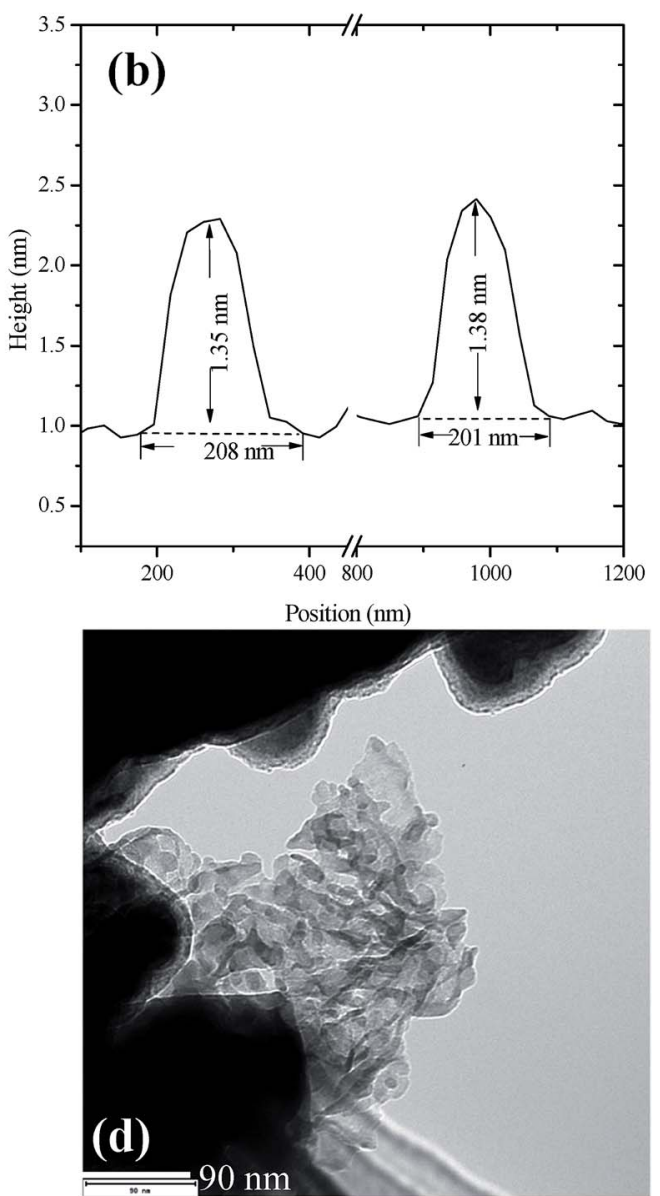

Fig. 7 (a) Tapping-mode AFM images of exfoliated selenate ettringite nanoparticles on mica, inset: colloid sample exhibiting the Tyndall effect after two months. (b) Associated cross-sectional profile of exfoliated selenate ettringite nanoparticles, (c) XRD patterns of the colloid suspension of selenate ettringite nanoparticles in butanol, inset: colloid sample exhibiting the Tyndall effect. (d) TEM images of exfoliated selenate ettringite.

unstable than the layered structure, ettringite may be more easily exfoliated into single nanoparticles. In this study, highly hydrophilic polar solvents, such as ethanol and butanol, were evaluated for exfoliation of ettringite. These hydrophilic polar solvent molecules not only containing $\mathrm{OH}$ groups but also has larger molecular sizes than oxoanions, preventing the exfoliated columnar parts from stacking again.

Selenate ettringite was tested for exfoliation by shaking in ethanol for $2 \mathrm{~h}$, which produced unstable suspensions and precipitated after a few minutes with minor exfoliation of selenate ettringite. In addition, the solid residues exhibited a similar XRD pattern to destructuralized selenate ettringite in sulfate, implying that the selenate ettringite could also be destructuralized by ethanol (Fig. S2 in the ESI $\dagger$ ). However, ethanol molecules are inefficient at pushing apart the high charge density columnar parts of ettringite. In contrast, a translucent colloidal solution was obtained after dispersing selenate ettringite in butanol. The resulting colloidal solution was centrifuged at $3000 \mathrm{rpm}$ for $10 \mathrm{~min}$, and the aggregate was recovered from the suspension. The prepared colloidal selenate ettringite nanoparticle suspension $\left(\sim 0.4 \mathrm{~g} \mathrm{~L}^{-1}\right)$ was stably transparent for more than 2 months (Fig. 7(a)). The particle size of the colloid solution was measured via dynamic light scattering. The mean spherical diameter was approximately $220 \mathrm{~nm}$, which is smaller than the width $(2 \mu \mathrm{m})$ and length $(15 \mu \mathrm{m})$ of selenate ettringite particles as observed by TEM and SEM. The AFM images revealed the vertical profiles of the exfoliated selenate ettringite particles (Fig. 7(a)). Based on the AFM images, the particle thickness was approximately $1.4 \mathrm{~nm}$, suggesting the presence of assemblies comprising several nanocolumnar parts (Fig. 7(b)). Moreover, the length of the exfoliated selenate ettringite particles was approximately $200 \mathrm{~nm}$, which is consistent with the results observed via dynamic light scattering. After centrifugation at $10000 \mathrm{rpm}$ for $20 \mathrm{~min}$, the obtained slurry showed no apparent peaks except for a broad peak at approximately $25^{\circ}$. The blank XRD pattern is belong to the steel sample holder. Because of the low intensity of the exfoliated selenate ettringite diffraction peak, the sample holder without loading any sample was also characterized for avoiding confusion (Fig. 7(c)). This is one of the characteristics for the formation of nanoparticles via exfoliation. The TEM image of exfoliated selenate ettringite gel dispersed in butanol 
clearly showed the exfoliation of selenate ettringite to nanoparticles (Fig. 7(d)), which is consistent with the AFM images. We demonstrated that selenate ettringite could be directly exfoliated as nanoparticles in polar solvents, and the carbon chain length of organic solvent molecules is one of the main factors that affect ettringite exfoliation. In addition, the exfoliation mechanism of selenate ettringite was discussed above. If the guest anion or molecules presents higher affinity than the original anions which are accommodate in the intercolumn space to ettringite, the exfoliation phenomenon will be happened. Therefore, sulfate or other kinds of ettringite could also have potential to be exfoliated as nanoparticles under the proper condition.

\section{Conclusions}

The possibility of ettringite to be exfoliated as columnar structural nanoparticles was preliminarily investigated. The phenomenon of selenate ettringite destructuralization was observed when this material soaked in high concentrations of sulfate. Characterization via XRD, Raman spectroscopy, TEM, and EXAFS revealed that the columnar structure of destructuralized selenate ettringite was maintained. A colloidal solution of selenate ettringite was produced when it was soaked in butanol, resulting from the strongly polar solvent molecules forming hydrogen bonds with structural water molecules. The AFM observations confirmed that the thickness of the exfoliated part of exfoliated selenate ettringite was approximately $1.4 \mathrm{~nm}$. Ettringite can be exfoliated to nanoparticles with a columnar structure, which represents a new line of research on the development of the chemistry of ettringite. Furthermore, the results clearly revealed the possibilities of ettringite as exfoliated columns dispersed in a solvent. This finding may have potential use in many applications, e.g., construction, electronics, and catalysis.

\section{Conflicts of interest}

The authors declare no competing financial interest.

\section{Acknowledgements}

Financial support was provided to KS by the Japan Society for the Promotion of Science (JSPS) KAKENHI (A) (No. JP16H02435). The EXAFS experiments were performed at the Kyushu University Beam line (SAGA-LS/BL06) with proposal No. 2016 IIK002.

\section{References}

1 Q. Wang and D. O'Hare, Recent advances in the synthesis and application of layered double hydroxide (LDH) nanosheets, Chem. Rev., 2012, 112, 4124-4155.

2 M. Tahir and N. S. Amin, Photocatalytic reduction of carbon dioxide with water vapors over montmorillonite modified $\mathrm{TiO}_{2}$ nanocomposites, Appl. Catal., B, 2013, 142, 512-522.

3 J. C. Tan, P. J. Saines, E. G. Bithell and A. K. Cheetham, Hybrid nanosheets of an inorganic-organic framework material: facile synthesis, structure, and elastic properties, ACS Nano, 2011, 6, 615-621.

4 J. H. Kang, S. M. Paek and J. H. Choy, Porous SnO2/layered titanate nanohybrid with enhanced electrochemical performance for reversible lithium storage, Chem. Commun., 2012, 48, 458-460.

5 M. Răciulete, G. Layrac, F. Papa, C. Negrilă, D. Tichit and I. C. Marcu, Influence of Mn content on the catalytic properties of $\mathrm{Cu}-(\mathrm{Mn})-\mathrm{Zn}-\mathrm{Mg}$-Al mixed oxides derived from LDH precursors in the total oxidation of methane, Catal. Today, 2017, DOI: 10.1016/j.cattod.2017.01.013.

6 A. C. S. Alcantara, P. Aranda, M. Darder and E. Ruiz-Hitzky, Bionanocomposites based on alginate-zein/layered double hydroxide materials as drug delivery systems, J. Mater. Chem., 2010, 20, 9495-9504.

7 J. Plank, D. Zhimin, H. Keller, F. V. Hössle and W. Seidl, Fundamental mechanisms for polycarboxylate intercalation into C3A hydrate phases and the role of sulfate present in cement, Cem. Concr. Res., 2010, 40, 45-57.

$8 \mathrm{~J}$. W. Anthony, R. A. Bideaux, K. W. Bladh and M. C. Nichols, Handbook of Mineralogy: Borates, Carbonates, Sulfates, Mineral Data Publishing, Tuscon, AZ, 2003.

9 G. Kakali, S. Tsivilis, E. Aggeli and M. Bati, Hydration products of C3A, C3S and Portland cement in the presence of $\mathrm{CaCO}_{3}$, Cem. Concr. Res., 2000, 30, 1073-1077.

10 H. F. W. Taylor, Crystal structures of some double hydroxide minerals, Mineral. Mag., 1973, 39, 377-389.

11 M. L. D. Gougar, B. E. Scheetz and D. M. Roy, Ettringite and C-S-H Portland cement phases for waste ion immobilization: A review, Waste Manag., 1996, 16, 295-303.

12 D. H. Moon, J. R. Lee, D. G. Grubb and J. H. Park, An assessment of Portland cement, cement kiln dust and Class C fly ash for the immobilization of $\mathrm{Zn}$ in contaminated soils, Environ. Earth Sci., 2010, 61, 1745-1750.

13 R. L. Norman, S. E. Dann, S. C. Hogg and C. A. Kirk, Synthesis and structural characterisation of new ettringite and thaumasite type phases: $\mathrm{Ca}_{6}\left[\mathrm{Ga}(\mathrm{OH})_{6} \cdot 12 \mathrm{H}_{2} \mathrm{O}\right]_{2}\left(\mathrm{SO}_{4}\right)_{3} \cdot 2 \mathrm{H}_{2} \mathrm{O}$ and $\mathrm{Ca}_{6}\left[\mathrm{M}(\mathrm{OH})_{6} \cdot 12 \mathrm{H}_{2} \mathrm{O}\right]_{2}\left(\mathrm{SO}_{4}\right)_{2}\left(\mathrm{CO}_{3}\right)_{2}, \mathrm{M}=\mathrm{Mn}$, Sn, Solid State Sci., 2013, 25, 110-117.

14 A. A. Kozak, A. J. Kozak, Z. Kowalski and K. WieczorekCiurowa, Synthesis of the ettringite containing chromium (III) and chromium (VI), Pol. J. Chem. Technol., 2002, 4, 1718.

15 M. Zhang and E. J. Reardon, Removal of B, Cr, Mo, and Se from wastewater by incorporation into hydrocalumite and ettringite, Environ. Sci. Technol., 2003, 37, 2947-2952.

16 N. Saikia, S. Kato and T. Kojima, Behavior of B, Cr, Se, As, Pb, $\mathrm{Cd}$, and Mo present in waste leachates generated from combustion residues during the formation of ettringite, Environ. Toxicol. Chem., 2006, 25, 1710-1719.

17 S. C. B. Myneni, S. J. Traina, T. J. Logan and G. A. Waychunas, Oxyanion behavior in alkaline environments: sorption and desorption of arsenate in ettringite, Environ. Sci. Technol., 1997, 31, 1761-1768.

18 A. E. Moore and H. F. W. Taylor, Crystal structure of ettringite, Acta Crystallogr., Sect. B: Struct. Crystallogr. Cryst. Chem., 1970, 26, 386-393. 
19 M. R. Hartman, S. K. Brady, R. Berliner and M. S. Conradi, The evolution of structural changes in ettringite during thermal decomposition, J. Solid State Chem., 2006, 179, 1259-1272.

20 B. Ravel and M. Newville, ATHENA, ARTEMIS, HEPHAESTUS: data analysis for X-ray absorption spectroscopy using IFEFFIT, J. Synchrotron Radiat., 2005, 12, 537-541.

21 M. Newville, IFEFFIT: interactive XAFS analysis and FEFF fitting, J. Synchrotron Radiat., 2001, 8, 322-324.

22 D. J. Hassett, G. J. McCarthy, P. Kumarathasan and D. Pflughoeft-Hassett, Synthesis and characterization of selenate and sulfate-selenate ettringite structure phases, Mater. Res. Bull., 1990, 25, 1347-1354.

23 I. Baur and C. A. Johnson, The solubility of selenate-AFt $\left(3 \mathrm{CaO} \cdot \mathrm{Al}_{2} \mathrm{O}_{3} \cdot 3 \mathrm{CaSeO}_{4} \cdot 37.5 \mathrm{H}_{2} \mathrm{O}\right)$ and selenate-AFm $\left(3 \mathrm{CaO} \cdot \mathrm{Al}_{2} \mathrm{O}_{3} \cdot \mathrm{CaSeO}_{4} \cdot x \mathrm{H}_{2} \mathrm{O}\right)$, Cem. Concr. Res., 2003, 33, 1741-1748.

24 B. Guo, K. Sasaki and T. Hirajima, Characterization of the intermediate in formation of selenate-substituted ettringite, Cem. Concr. Res., 2017, 99, 30-37.

25 H. Li, S. Wei, C. Qing and J. Yang, Discussion on the position of the shear plane, J. Colloid Interface Sci., 2003, 258, 40-44.
26 S. C. B. Myneni, S. J. Traina, G. A. Waychunas and T. J. Logan, Vibrational spectroscopy of functional group chemistry and arsenate coordination in ettringite, Geochim. Cosmochim. Acta, 1998, 62, 3499-3514.

27 K. Nakamoto, Infrared and Raman spectra of inorganic and coordination compounds, John Wiley \& Sons, Ltd, 1986.

28 D. Torréns-Martín, L. Fernández-Carrasco, S. MartínezRamírez, J. Ibáñez, L. Artús and T. Matschei, Raman spectroscopy of anhydrous and hydrated calcium aluminates and sulfoaluminates, J. Am. Ceram. Soc., 2013, 96, 3589-3595.

29 B. Guo, K. Sasaki and T. Hirajima, Selenite and selenate uptaken in ettringite: Immobilization mechanisms, coordination chemistry, and insights from structure, Cem. Concr. Res., 2017, 100, 166-175.

30 K. Mizuno, Y. Miyashita, Y. Shindo and H. Ogawa, NMR and FT-IR studies of hydrogen bonds in ethanol-water mixtures, J. Phys. Chem., 1995, 99, 3225-3228.

31 S. Burikov, T. Dolenko, S. Patsaeva, Y. Starokurov and V. Yuzhakov, Raman and IR spectroscopy research on hydrogen bonding in water-ethanol systems, Mol. Phys., 2010, 108, 2427-2436. 